\title{
Letter to editor: Obituary
}

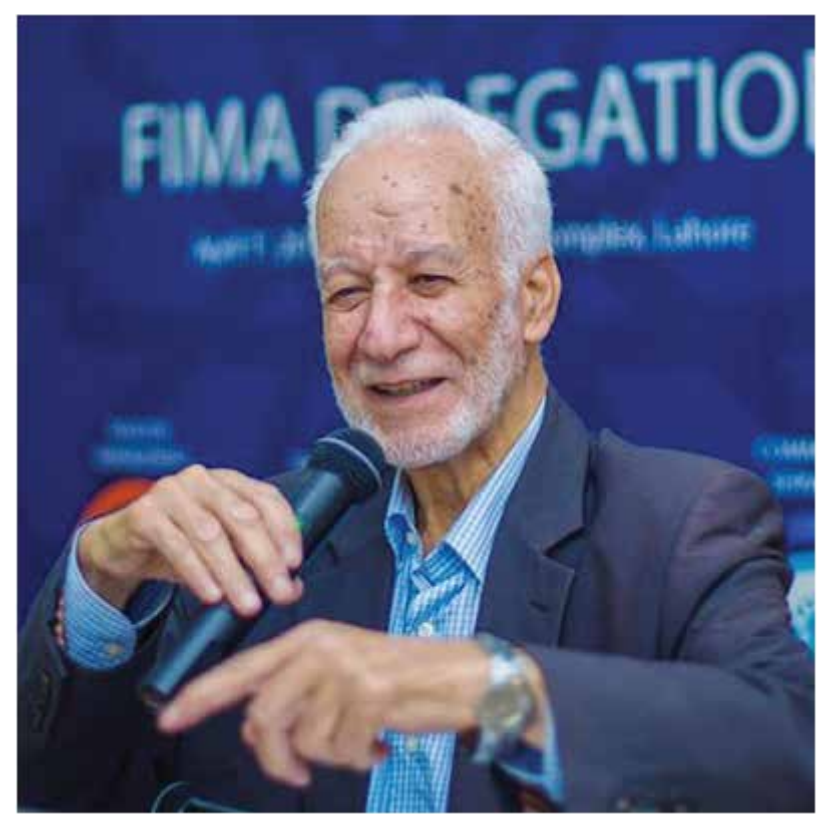

Prof. Dr. Aly Mishal (1938-2018)

Bangladesh Journal of Medical Science Vol. 17 No. 04 October'18. Page : 694-695 DOI: http://dx.doi.org/10.3329/bjms.v17i4.38342

In memory of Dr. Ali Mishal

It's very hard to describe the life of a man who is larger than life, and I don't know where to start. Is it the happy child, who was born in a large house with a garden in Lifta, a prosperous Jerusalem suburb? Or the school child who had to endure the cruelty of the British mandate on Palestine? Or the twice refugee, who after his prosperous childhood, landed with his family in a tent in the Zarqa refugee camp in Jordan, to grow up in extreme poverty?

Due to his brilliance and academic achievements, he was accepted for his last school year in the prestigious Al-Hussain College in Amman, from which he graduated with honours.

With the extreme poverty of his family, the suggestion was that Ali will train as a teacher like his elder brother, to help his family. But his elder brother, also a teacher, came and swore by Allah that Ali was to study medicine, which was more facilitated by Dr. Ali gaining a UNRWA scholarship to study medicine at Alexandria University.

His refugee story is an example of all Palestinians. After the house next to their house in Lifta was blown up by Zionists in 1948, his mother carried the four children and travelled on foot to a refugee camp on the west bank. His father stayed behind to fight although all he has was an old sword. With the Nakba in 1948, the Zionists occupied Lifta and his father left to join him in the refugee camp. After which, they went to live with his uncles in Sheikh Jarrah, a prosperous Jerusalem suburb. Alas, it was only for a few months, as the Zionists occupied that part of Sheikh Jarrah and the Mishal family went to live in a tent in Zarqa refugee camp.

Dr. Ali went to Alexandria Medical School, from which he graduated with honours in 1964. On his return to Jordan, where the scene was rich with people thinking about resistance to liberate Palestine, he was one of the first pioneers on the scene for which he kept going in and out of prison for his activities until he was imprisoned without a term, only to come out after 1967 Naksa, when the Jordanian government decided to free all political prisoners.

Dismayed by the infighting and corruption in resistance groups which culminated in the black September in 1970, Ali decided to go to the US for specialising.

In the US, he was very active in organising Palestinian activities and support for refugees and propagating the Palestinian cause, culminating in him becoming

Correspondence to: Dr. Tareq Tahboub, Ex-chair of the Jordan Medical Association, Ex-chair PalMed UK, Ex-chair PalMed Europe, A proud member of Dr Aly Mishal's fan club email: amdaoud@just.edu.jo 
the first president of American Muslim Associations for Palestine in 1981.

Back to Amman, in the mid-80s, where he started working at the Islamic Hospital, till his admission in his final illness Dr. Ali built a bastion of knowledge, education, continuous medical training, establishing Islamic medical ethics, publishing and clinical administration.

We need volumes to describe Dr. Mishal's activities, as a philanthropist, he was a founding member of FIMA, its president and CEO. FIMA's humanitarian missions cover the world. His FIMA year book project enriches our knowledge on medical humanities a lot ${ }^{1-9}$. He was a founder advisor of SCOPUS indexed journal BJMS, his role was like its founder Prof. Muazzam $^{10}$.

Precision, vision, decision, discipline knowledge and education were the words that Dr. Ali lived by.

Some fond memories of him include:

During my campaign, which I won, for chair of the Jordan Medical Association in 1999, I arrived at 8.30 to find Dr Ali in the campaign tent from 8 o'clock and he stayed till the result was announced.

Travelling to Cairo with him, he went to sleep immediately after takeoff, and we had the worst landing ever, but Dr. Ali was still asleep. I woke him up and told him about the landing, he told me that was up the night before till 3.00 a.m. working on the nomination papers of another great; Dr. Adnan Jaljuli for a prize. Whilst returning from Cairo, he offered me a lift where Umm Alraed his wife was waiting.

\section{References:}

1. MISHA'L, Aly A. The Concept of Successful Aging. International Journal of Human and Health Sciences (IJHHS), 2017;01(01): 22-25. doi:http://dx.doi. org/10.31344/ijhhs.v1i1.4.

2. ALI, Albar Mohammed; HASSAN, Chamsi Pasha. Artificial nutrition and hydration. International Journal of Human and Health Sciences (IJHHS), 2017;01(01): 18-21. doi:http://dx.doi.org/10.31344/ijhhs.v1i1.3.

3. A, Misha'l Aly. Drug Prescribing to the Elderly Patients. International Journal of Human and Health Sciences (IJHHS),2017;01(02): 65-69, doi:http://dx.doi. org/10.31344/ijhhs.v1i2.12.

4. HASSAN, Chamsi Pasha; ALI, Albar Mohammed. Withdrawing or Withholding Treatment. International Journal of Human and Health Sciences (IJHHS), 2017;01(02):59-64, doi:http://dx.doi.org/10.31344/ijhhs.vli2.11.

5. MOHAMMED ALI, Albar; HASSAN, Chamsi Pasha. Futility of Medical treatment. International Journal of Human and Health Sciences (IJHHS),2018;02()1): 13-17. doi:http://dx.doi.org/10.31344/ijhhs.v2i1.19.

6. HASSAN, Chamsi Pasha; MOHAMMED ALI, Albar. DoNot-Resuscitate Orders: Islamic viewpoint. International Journal ofHuman and Health Sciences (IJHHS), 2018;02()1): 8-12. doi:http://dx.doi.org/10.31344/ijhhs.v2i1.18.
As soon as he saw her, there was a sparkle in his eyes and his infectious smile grew wider.

Buying him a copy of the movie (The wind that shook the barley) which is about the Irish struggle and British occupation, and returning it to me with tears in his eyes, telling me it reminded him of the British occupation of Palestine where the soldiers of Abu Tanoora (the Scots wearing the skirts), harassing and arresting people from Lifta.

Dr. Ali Mishal's heart was full of Islam, Palestine, his family, humanitarian work and medical education and training. His waqf is his work and publications on all of the above. His charity was from America to Jordan treating poor patients free of cost. His loss was felt from Jordan to all over the World wherever the humanity is in crisis.

May Allah (SWT) accept him and grant him the highest ranks of Paradise, and grant his family peace, patience and solace. His life was a fulfilment of inaah lillah wa inna ilayhi rajioon, as another Islamic great, Professor Geoffrey Lang said in his lecture in Manchester that life is summarised on one sentence which is: to Allah we belong and to Him we shall return.

Dr. Tareq Tahboub

Ex-chair of the Jordan Medical Association

Ex-chair PalMed UK

Ex-chair PalMed Europe

A proud member of Dr Ali Mishal's fan club

7. AHMAD, Wafa 'a Qasem. Spiritual Care at The End Of Life: Western Views and Islamic Perspectives. International Journal of Human and Health Sciences (IJHHS),2018;02(02):65-70. doi:http://dx.doi. org/10.31344/ijhhs.v2i2.28.

8. AKHTAR, Sohail; MEMON, Abdul Majeed. Physician's Role At Time Of Death. International Journal of Human and Health Sciences (IJHHS), 2018;02(03): 126-130, oi:http://dx.doi.org/10.31344/ijhhs.v2i3.39.

9. Al-Arouj M, Bouguerra R, Buse J, Hafez S, Hassanein $\underline{\mathrm{M}}$, Ibrahim MA, Ismail-Beigi F, El-Kebbi I, Khatib

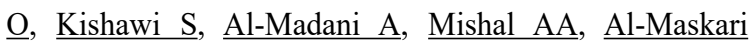
M, Nakhi AB, Al-Rubean K.Recommendations for management of diabetes during Ramadan. Diabetes Care. 2005;28(9):2305-11.

10. MUAZZAM, Naima; AL-MAHMOOD, Abu Kholdun. In memory of Prof. Ghulam Muazzam: legendary medical scholar of Bangladesh. Bangladesh Journal of Medical Science, 2015; 14 (2): 117-118. doi:http://dx.doi. org/10.3329/bjms.v14i2.18261. 